\title{
Pendidikan Nasional, Kesempatan Kerja dan Pengembangan Sumberdaya Manusia
}

\author{
Oleh : E. Zainal Abidịn
}

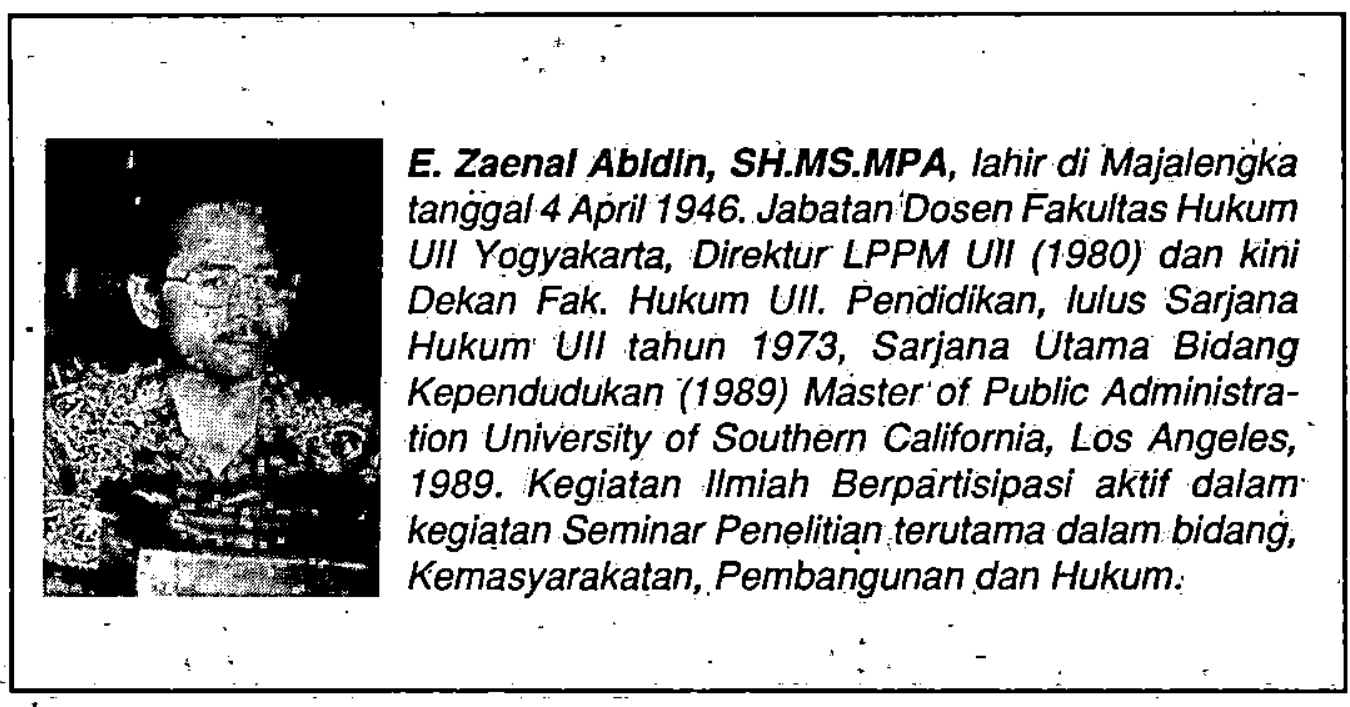

Permasalahan

Pendidikan Nasional dalam kaitannya dengan ketenagakerjaan menyangkut segenap usaha untuk meningkatkan produktivitasșeluruh sumbèr daya manusia yaitu tersedianya tenagakerja yäng terdidik dan terampil sejalan dengan laju pertumbuhan pembangunan.

Dalam kaitannya dengan strategi, pembangunan yang berorientași pada pemerataan, kesempatan - kerja dan pertumbuhan ekonomi, masih terdapat. kesenjangan antara angkatan kerja, tenagakerja dengan kesempatan kerja yang tersedia. Kesenjangan tersebut terjadi sebagai akibat pilihan teknologi yang - berörientasi padat modal di satu pihak dan lemahnya lembaga pendidikan dalam mengejarketinggalan tuntutan keterampilan yang dibutuhkan oleh masyarakat industri.
Diperlukan suatu perencanaan ketenaga kerjaan yang sinkron dengan perencanaan pendidikan dan atau sebaliknya sinkronisasi antara perencanaan pendidikan dengan perencanaan ketenaga kerjaan.

Pembahasan

\section{i. Angkatan Kerja}

Angkatan kerja adalah mereka yang telah mencapai usia kerja, telah bekerja, . dan mereka yang secara aktif mencari pekerjaan. Dengan mengetahui keadaan angkatan kerja dapat diketahui kesempatan kerja apa dan berapa besar kesempatan kerja yang diperlukan untuk menampung keseluruhan angkatan kerja yang tersedia.

Jumlah angkatan kerja/tenaga kerja banyak ditentukan oleh variabel kependudukan (jenis kelamin, usia) sedang kualitas atau mutu tenaga kerja terutama dipengaruhi oleh kondisi dankebijaksanaan. 
kependidikan. Diperkirakan selama Repelita V jumlah angkatan kerja meningkat dari 71 . juta pada tahun 1988 menjadi sekitar 82 juta pada tahun 1993. $\mathrm{Hal}$ tersebut mengandung arti terdapat peningkatan sebanyak 11 juta orang atau sebanyak 2.229.500 orang pertahun (2.96\%). Dari sejumlah itu, sebagaian $(50,19 \%)$ memiliki pendidikan rendah yaitu sekolah dasar(SD). Kondisi angkatan kerja dengan pendidikan rendah akan menghasilkan produkstivitas yang rendah dengan kualitas yang rendah pula. Pada tabel 1,2dapat dilihat proyeksi pertumbuhan dan pertambahan angkatan kerja serta perkiraan tambahan angkatankerja menurut pendidikàn selama periode tahun 1988 1993

\section{TABEL : 1 Analisa Tambahan} Angkatan Kerja dan Kesempatan Kerja Menurut Tingkat Pendidikan ( 1988 - 1993 ) Dalam Ribuan

\begin{tabular}{|c|c|c|c|c|c|}
\hline $\mathrm{Na}$ & Taghted/Jeis Pondilian & $\begin{array}{c}\text { Tambahan } \\
\text { Aczkalas Xerja }\end{array}$ & 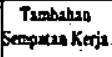 & 5 & Nexpimbangzo \\
\hline $\begin{array}{l}1 . \\
2 \\
3 . \\
4 . \\
3 . \\
0 . \\
7 . \\
2 \\
9 .\end{array}$ & 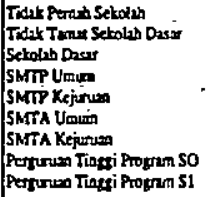 & 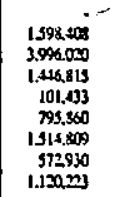 & $\begin{array}{r}2372 \\
3.762 \\
3.021 \\
620 \\
135 \\
1353 \\
494 \\
84 \\
58\end{array}$ & $\begin{array}{l}21,65 \\
34,34 \\
2,58 \\
5,66 \\
1,42 \\
3.54 \\
4.51 \\
0.77 \\
0.53\end{array}$ & 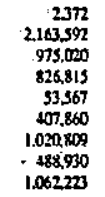 \\
\hline & IUMLAH & 11.146 .688 & 10.954 & 100 & 192,498 \\
\hline
\end{tabular}
inem 1991 (revisi)

Tabel : 2 Pérkiraan Tambahan Angkatan Kerja Menurut Pendidikan Repelita V ( 1988 - 1993)

\begin{tabular}{|c|c|c|c|c|}
\hline \multirow{2}{*}{$\mathrm{No}$} & \multirow{2}{*}{ Tirzkplyenls Pendidikan } & \multicolumn{2}{|c|}{ Kejuarano Peadiditon Fortal } & \multirow{2}{*}{$\begin{array}{c}\text { Tumbuban } \\
\text { Anpkstan Kerjo }\end{array}$} \\
\hline & & Jumlab & $\%$ & \\
\hline $\begin{array}{l}1 . \\
2 \\
3 . \\
4 . \\
3 . \\
6 . \\
2 . \\
8 . \\
9 .\end{array}$ & 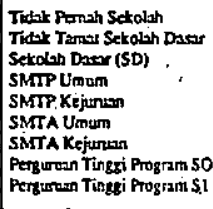 & $\begin{array}{r}2.050 .2 \\
9.124 .0 \\
1.855 .2 \\
1.30 .4 \\
1.030 .4 \\
1.941 .9 \\
739.4 \\
1.437 .1\end{array}$ & $\begin{array}{r}1+.54 \\
35.85 \\
12.90 \\
0.91 \\
7.14 \\
13.59 \\
5.14 \\
10.05\end{array}$ & $\begin{array}{r}1.598,408 \\
3.996,090 \\
1.446 .815 \\
101.433 \\
795.960 \\
1.514 .809 \\
572,9,90 \\
1.120 .223\end{array}$ \\
\hline & JUMILAY & 14.294 .6 & 100 & 11.146 .498 \\
\hline
\end{tabular}

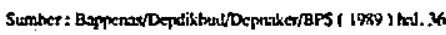

\section{Kesempatan Kerja}

Pendekatan yang mengutamakansisi permintaan (model Keynes) di mana modal merupakan penggerak pembangunan berpendapat bahwá kesempatan kerja tercipta karena adanya produksi barang dan jasa. Semakin banyak barang dan jasa yang dihasilkan, semakin banyak pula kesempatan kerja diciptakan dengancatatan bila teknologi yang digunakan tidak mengalami perubahan. Oleh karena itu untukmenumbuhkanperluasan kesempatan kerja harus ditujukan pada mendirikan kegiatan-kegiatan yang menghasilkan barang yang kemudian akan menimbulkan permintaân terhadap masukan (input) produksi yaitu antara lain tenaga kerja. Akan tetapi untuk negara kita dimana terdapat ketidak seimbangan distribusi penduduk serta tenaga kerja berlebih pendekatan tersebuit dipandang tidak tepat. Dalam pilihanteknologi cendenungmemilih teknologi padat modal (capital intensive) sehingga banyak tenaga kerja yang tidak terpakai.Pengangguran semakin bertambah setiap tahun di samping terdapatnya pengangguran terselubung (disguised unemployment) yaitu mereka yang bekerja tidak sesuai dengan latar belakang pendidikan serta ketrampilan yang dimiliki (underutilization).

Menurut Hidayat (1982, hal. 23) untuk kondisi tenaga kerja kita, pilihan teknologi hendaknya disesuaikan dengan kuantitas dan kualitas sumber daya yang ada dan bukan sebaliknya (the kind of technology chosen must be dictated by the quality of the human resources available not the choice of technology be will be dictated by the owners of production). Pada

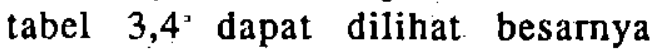
pengangguran di Indonesia menurut tingkat 
pendidikan serta relevansi pekerjaan tamatan perguruan tinggi sebagaimana dikemukakan oleh Amdt dan Sundrum serta Palmier (Sumamo. 1986, hal 5 dan 6)

Tabel 3. Pengangguran di Indonesia menurut lokasi dan tingkat pendidikannya (\%)

\section{Tabel 3.}

Pengangguran di Indonesia menurut lokasi dan tingkat pendidikannya (\%)

\begin{tabular}{|c|c|c|c|c|c|c|c|}
\hline \multirow{2}{*}{ Pendidikan } & \multicolumn{3}{|c|}{ Kota } & \multicolumn{3}{|c|}{ Desa } & \multirow{2}{*}{ Tolal } \\
\hline & Pria & Wnt. & Tot. & Pria & Wnt. & Tok. & \\
\hline $\begin{array}{l}\text { 1. S.D. atau kurang } \\
\text { 2 Sek. Menerigah } \\
\text { 3. Di ams Sek. } \\
\text { Menengar }\end{array}$ & $\begin{array}{r}15,6 \\
18.2 \\
5.6\end{array}$ & $\begin{array}{r}9,0 \\
24,4 \\
16,4\end{array}$ & $\begin{array}{l}123 \\
213 \\
110\end{array}$ & $\begin{array}{l}48 \\
129 \\
166\end{array}$ & $\begin{array}{r}3.8 \\
.170 \\
32\end{array}$ & $\begin{array}{r}4.2 \\
14.9 \\
9.9 \\
:\end{array}$ & $\begin{array}{r}8.25 \\
18.13 \\
10.45\end{array}$ \\
\hline
\end{tabular}

Sumber : Amd dan Sundrum ( 1980 : 167;)

Tabel 3. menunjukkan bahwa secara keseluruhan persentase lulusan/tamatan perguruan tinggi yang menganggur lebih rendah dari kelompok tamatan sekolah menengah, tetapi lebih tinggi dari kelompok yang hanya berpendidikan rendah. Dáta tersebut juga menunjukkan adanya perbedaan antara daerah perkotaạn dan pedesaan. Di kota, persentase wanita tamatan perguruan tingggi yang menganggur jauh lebih tinggi dari pada pria. Di desa, persentase pria penganggur tamatan perguruan tinggi lebih tinggi dari pada kelompok wanitanya. Keadaan tersebut mungkin karena di desa relatip sedikit wanita berpendidikan tinggi.di kota banyak wanita berpendidikan tinggi yang tidak bekerja, meskipun relatiplebih banyak pekerjaan yang sesuai dengan taraf pendidikan mereka.

Bentuk lain dari pemborosan modal yang ditanamkan di pendidikan tinggi iälah tamatan tersebüt bekerja, tetapi tidak sesuai dengan pendidikannya. Mungkin bidangnya yang kurang sesuai, dan mungkin pula pekerjaan tertentu sebenarnya hanya memerlukan tingkat pendidikan menengah.
Masalah relevansi okupasi para tamatan perguruan tinggi di Indonesia pemah di kaji oleh Palmier (1982 : 697, 704).

-Tabel 4 : Relevansi Okupasi para tamatan perguruan tinggi ( $\%$ )

\begin{tabular}{|c|c|c|c|c|c|}
\hline \multirow{2}{*}{ 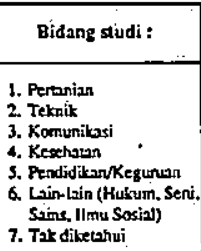 } & \multirow{2}{*}{$\begin{array}{c}\text { persen dr: } \\
\text { popl. } \\
3 \\
10 \\
5 \\
6 \\
30 \\
39 \\
7\end{array}$} & \multicolumn{3}{|c|}{$\begin{array}{l}\text { OXUPAS! RELEVAN. } \\
\text { Sarmud. Sarja. X }\end{array}$} & $\begin{array}{l}\text { OKUPASI TIDAK } \\
\text { RELEVAN }\end{array}$ \\
\hline & & $\begin{array}{l}46 \\
45 \\
20 \\
78 \\
69 \\
35\end{array}$ & $\begin{array}{l}28 \\
44 \\
26 \\
56 \\
70\end{array}$ & $\begin{array}{l}37 \\
45 \\
23 \\
67 \\
70 \\
32\end{array}$ & $\begin{array}{l}63 \\
55 \\
77 \\
33 \\
30 \\
68 \\
0\end{array}$ \\
\hline Ratarat & 100 & 49 & $\$ 2$ & 46 & 34 \\
\hline \multicolumn{6}{|c|}{ Sumber : Palmier ( $1982: 697,704$ ) } \\
\hline
\end{tabular}

menunjukkan bahwa sarjana dan sarjana muda dari bidang.pendidikan/keguruandan kesehatanlah persentasenya paling tinggi dengan pekerjaan yang sesuai dengan tingkat/jenis bidang keahliannya. Dari bidang studi yang lain, lebih dari separoh pekerjaannya tidak/kurang relevan. Dikemukakan bahwa hanya 46 persen tamatan perguruan tinggi di Indonesia bekerja pada pekerjaan yang sesuai dengan keahliannya; sedangkan sebanyak 54 persen lainnya memiliki pekerjaan yang tidak atau kurang sesuai dengan keahliannya. Kelompok terakhir inilah yang mengalami underempolyment,sedikit lebih baik dari pada unemployment.

Kecenderungan perubahan teknologi akan terjadi apabila terjadi pergeseran struktur produksi. Secara terencana pemerintah melalui Repelita telah melakukan pergeseran struktur produksi dári sektor pertanian ke sektor industri pengolahan dan páda tahap tinggal landas perubahan menuju ke masyarakat industri. Daya tampung sektor pertanian semakin menurun sementara sektor industri penghasil barang modal dan eksporsifatnya semakin relatif padat modal dan padat teknologi sehingga jumlah pengangguran 
akan tetap besar. Pāda Repelita. V diperkirakan out put nasional tumbuhsekitar 5 persensetiaptahun akan tetapi kesempatan kerja yang diciptakan hanya tumbuh sekitar 2,5 persen. Akibatnya pengangguran akan meningkat jumlahnya (Soelistyo 1988, hal. 10).

Perubahan struktur ekonomi dari negara agraris menjadi negara industri mengakibatkan perubahan dalam bidang keahlian tenaga kerja yang berbeda dengan keahlian buruh tani. Tenaga profesional, teknisi ahli- (higher technician), teknisi industri (trade technician) dan juru teknik (tradesman) diperlukan dalam jumlah yang lebih besar. Dilihat dari struktur keahlian yang dimiliki tenaga kerja Indonesia masih terdapat kekurangan yang cukup besar ; tenaga profesional masih kurang dibandingkan dengan permintaan sektor industri sehingga banyak digûnakan tenaga asing; sarjana teknik Indonesiamasih belum masuk kategori manusia terampil dibandingkkan dengan Jepang, Korea, dán Taiwan; teknisi ahli, teknisi industri dan jun teknik tidak tersedia dan terlalu besar hasrat untuk masuk perguruan tinggi. Däpat disimpulkan bahwa hambatan utama pembangunan industri dalam dasa warsa 80-an terletak pada langkanya mutu tenaga kerja yang diperlukan di lapangan.Ini berarti pula dunia pendidikan kurang responsif dalam menyadiakan "high levelmanpower" yang diperlukan untuk pembangunan sekarang dan di masa mendatang (Hidayat. 1982, hal 25). Pada gambar la lb dapat dilihat bentuk piramida struktur jenjang tenaga kerja di Indonesia yaitu mengalami penyempitan di bagian tanah yang berarti kurangnya tenaga teknisi ahli dan tenaga teknis dengan akibat produksitvitas menjadi rendah

\section{Gambar : 1a. Perbandingan Struktur Keahlian Tenaga Kerja di Negara Industri} dan Indonesia

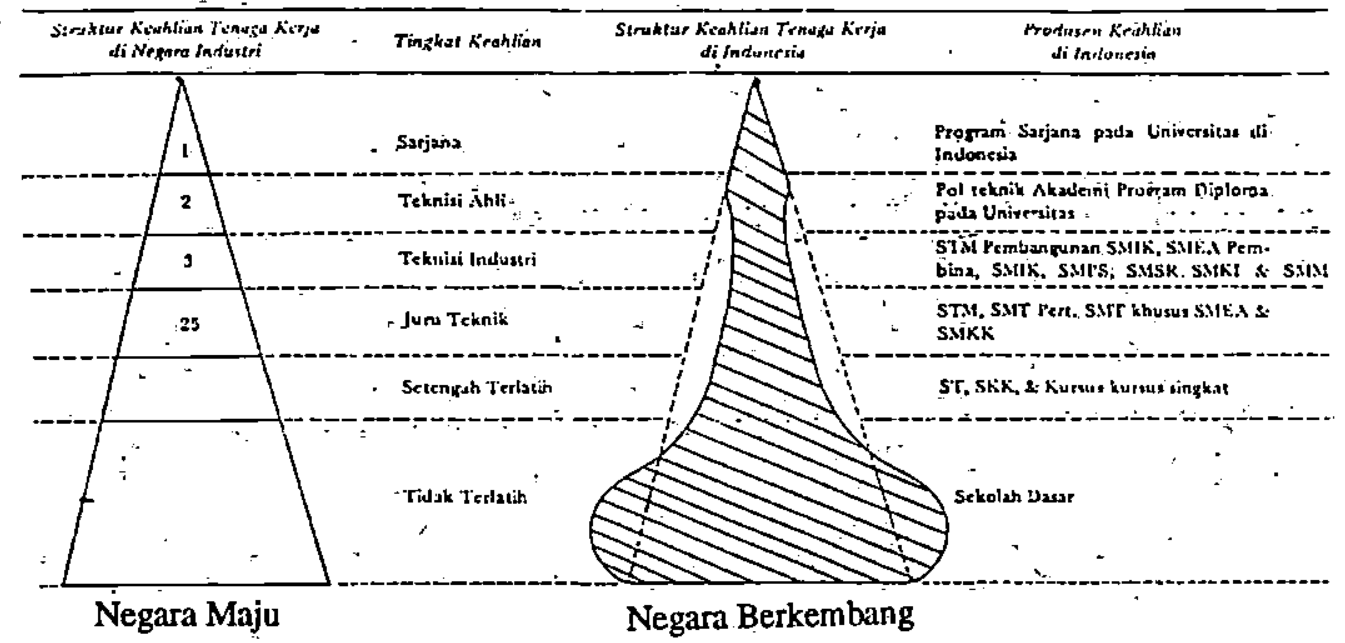

Sumber ミ PRISMA 4, April 1982 


\section{Sistem Pendidikan}

Tujuan pendidikan nasional untuk meningkatkan ketaqwaan, kecerdasan;keterampilan, mempertinggi budi pekerti, kepribadian, cinta tanah air dan mampu membangun dirinya sendiri serta pembangunan bangsa serta perluasan memperoleh pendidikan sekaligus mengarahkan pada kebutuhan pembangunan di berbagai bidang serta bahwa pendidikan adalah berlasung seumur hidup serta dilaksanakan dalam lingkungan sekolah, keluarga dan masyarakat merupakan kebijaksanaan yang cukup tepat dan mendukung terbentuknya manusia. Indonesia seutuhnya. Namun demikian dalam pelaksanaan terdapat berbagai variabel yang berpengaruh, kendala serta penyimpangan-penyimpangan seperti kendala budaya masyarakat, sistem pendidikan dan sistem kepegawaian yang berlaku di Indonesia sampai saat ini.

Semakin tersedia kesempatan memasuki pekerjaan sektorformal, semakin mendorong orang untuk memperoleh pendidikan (ijazah, diploma) yang lebih tinggi. Jumlah pelamar yang melebihi lowongan yang tersedia; pengembangan karier/promosi yang lebih cepat bagi lulusan sarjana di atas lulusan SLA mémacu orang mencari persyaratan lain di atas persyaratan minimal dengan mengikuti pendidikan tambahan ýang lebih tinggi. Sebagai akibat tidak tertampungnyaparalulusan SLP/SLA pada tingkat pendidikan Universitas telah banyak berdiri perguruan tinggi swasta atau sekolah-sekolah swasta yang hanya menyebabkan semakin bertumpuknya jumlah penganggur.

\section{Gambar 1b : Perbandingan Struktur Keahlian Tenaga Kerja Di Indonesia,} Pakistan dan Korea.

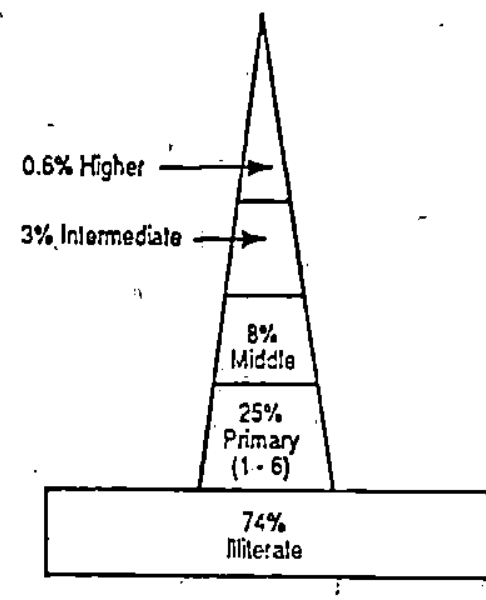

PAKISTAN $1985-8$

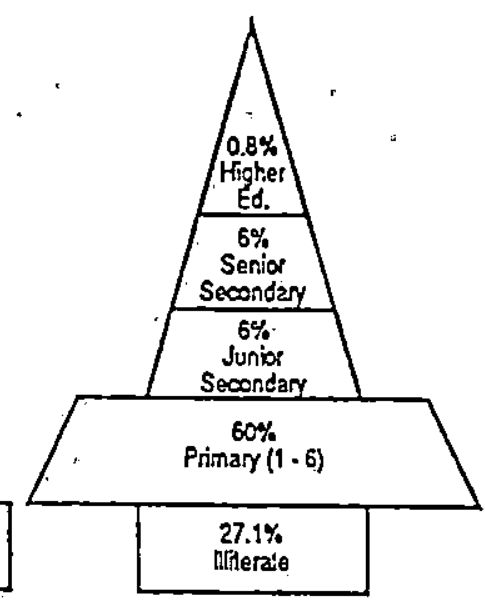

INDONESIA 1982

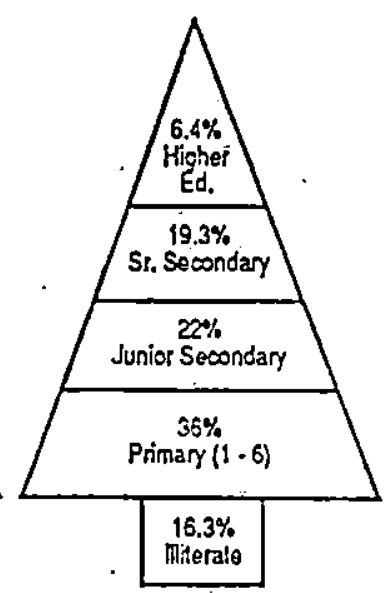

SOUTH KOREA 1975

Sumber : Depdikbud - USAID, Education and the Economy, 1992 hal 14. 
Dalam sistem pendidikan kita jumlah SLA Umum yang lebih banyak dari SLA kejuruan, sistem seleksi untuk memasuki perguruan tinggi yang lebih menguntungkan lulusan SLA Umum, perluasan program studi (SO,S2,S3,D1,D4 dst), memberikan kontribusi pula bagi membengkaknya jumlah mahasiswa dan lulusan sarjana.

Sistem kepegawaian untuk seumur hidup (sampai usia pensiun) dan tidak berorientasi pada tingkat ketrampilan, maka pendidikan dianggap sebagai suatu cara untuk meningkatkan gengsi seseorang dalam masyarakat dan semakin menambah sulit dalam penataan sistem pendidikan yang ada(Soemamo, 1986, hal 12,13) Sementara Soelistyo (1988, hal. 14) menilai bahwa kebijaksanaan yang mendorong peningkatan jumlah serta kualitas pendidikan formal tidak diimbangi oleh penyerapan tenaga kerja yang memilki pendidikan yang lebih tinggi yang diciptakan oleh kondisi ekonomi yang semakin berkembang. Di sisi lain tantangan kemajuan IPTEK dari dunia barat semakin memaksa lembaga-lembaga pendidikan untuk mampu memberikan respon kreatif untukmengangkatkehidupan bangsa sejajar dengan negara-negara maju. Sistem pendidikan harus mampu mempersiapkan bangsa untuk menghadapi perkembangan dunia yang semakin kompleks, memiliki sikap terbuka, percaya pada diri sendiri, berani mengambil resiko, bertanggung jawab, hidup sederhana dan bersikap produktif (Soedjatmoko, 1989, hal. 9)

Sementara itu jika kita tengok sistem pendidikan barat khususnya di Amerika menyertai percepatan pertumbuhan ekonomi pada tahun 50 dan 60 an memperlihatkan dengan jelaskebijaksanaan dan. pengembangan pendidikan yang diarahkan pada perkembangan ekonomi. Konsep "Human Capital", teorimodemisasi serta masa depan" perkembangan masyarakat post industri memberikan arah dan penetapan policy pemerintah Amerika. Kombinasi prospektif ekonomi dalam pendidikan sebagai human investment merupakan bahan utama penyusunan kebijaksanaan pemerintah federal dalam pengembangan pendidikan umum yang relevan dengan kebutuhan pembangunan ekonomi. Kompetisi serta timbulnya berbagai kelompok sosial untuk mengembangkan secara efektif human resources. Rakyat Amerika percaya bahwa tujuan pendidikan harus berkorelasi secara sistematik dengan proses pembangunan ekonomi sekalipun hanus dibayar dengan mahal dari sisi politik dan sosial. Terlepas dari kelemahan-kelemahan serta kritik terhadap pendekatan human capital dalam pendidikan para pemegang policy di Amerika yakin bahwa reformasi pendidikan yang berpijak pada semboyan: "Pendidikan Untuk Pembangunan Ekonomi Negeri" merupakan sesuatu yang benar dan efisien dan akan mendapatkan hasil yang sejalan dengan pandangan tentang 'bagaimana sebaiknya pendidikan diwujudkan serta apa yang sebaiknya diajarkan (Alan J. De Young, 1989)

Berbicara tentang kebijaksanaan serta arah pendidikan di negeri kita Indonesia dapat dikemukakan beberapa catatan sebagai berikut :

1. Konsep pembangunan Barat yang menekankan pada peningkatan GNP setinggi-tingginya dan secepat-cepatnya tidak mampu memecahkan masalahmasalah kemiskinan, keterbelakangan, kebodohan di negara-negara 
berkembang termasuk Indonesia. Oleh kârena-itu strategi pembangunan yang bersendi pada pemerataan, kesempatan kerja, nemberantas kemiskinan, kebodohan keterbelakangan adalah penting di samping meningkatkan pertumbuhan ékonomi.

2. Peningkatan pertumbuhan ekonomi nasional diperlukan akan tetapi tanpa harus mengorbankan sumber daya yang besar yang kita miliki. Masalahṇya iálah bagaimana meningkatkan pertumbuhàn ekonomi melalui pendayagunaan lebih efektif lagi variabel yang paling banyak kita miliki yaitu sumber daya manusia dikaitkan dengan altematif pemilihan teknologi serta berbagai kelembagaan yang menunjang proses pembangunan. Pembangunan yang dilaksanakanjangan sampai melenyapkan kebudayaan yang sudah mendarah daging dalam masyarakat atau pendekatan yang bersifat manusiawi. Strategi pembangunan jangka panjang melalui . struktur ekonomi yang seimbang yaitu kekuatan industri yang maju didukung kékuatan dan kemampuạn pertanian yang tangguh serta perdagangan luar negeri yang sejalan dengan pembangunan industri dan pertanian adalah cukup ideal walaupun sulit dalam pelaksanaan.

3. Agar dapat menunjang pembangunan, perlu dilakukan pergeseran fungsi pendidikan dari fungsi tradisional yang berupa estafeta nilai-nilai (budaya) menjadi berorientasi ke depăn yaitu berupaya mempersiapkan terbentuknya manusia yang mampu mengisi tenaga kerja masyarakat industri (manusia produktif) serta pengembangan nilainilai yang mendukung pembàngunan.
Dalambidang non ekonomikpendidikan berperan dalam mempersiapkan kondisi sikap mental dan orientasi yang lebih modern, memiliki disiplin nasional (kepatuhan, loyalitas) serta integritas nasional. Sikap yang positif dan aktif (optimistik), kepuasan atas pekerjaan dan mutu yang dihasilkan (commitment to work), berorientasi ke masa depan (futurism), berencana dan hemat, menghargai waktu (valuation on time), kompetisi yang sehat, dsb.

4. Perencanaan ketenaga kerjaan perlu memperhatikan keterkaitan antara pendidikan dan kesempatan kerja. Tujuan pendidikan selain meningkatkan pengetahuan perlu dikaitkan 'dengan kebijaksanaan kesempatan kerja. Demikian pula dalam membicarakan kesempatan kerja harús dikaitkan dengan peningkatan pendidikan tenaga kerja. Peran pendidikan yang lebih tepat adalah menyiapkan tenaga kerja yang mempunyai pengetahuan dan keterampilan yang bersifat umum di bidangnya sehingga lebih adaptif terhadap perkembangan spesifikasi pekerjaan yang dibutuhkan di dunia industri. Sementara untuk pembekalan keterampilan khusus yang diperlukan lebih mudah dan murah jika diselenggarakan melalui "on the job training" pada pusat-pusat industri yang bersangkutan. Sekolah-sekolah kejuruan dibatasi sesuai dengan kebutuhan mendesak. Sekolah-sekolah umum selain lebih efisien juga lebih fleksibel dan dirasakan lebih demokratis.

5. Sudah saatnya dirintis sistem rekruitmen tenaga kerja lebih mengutamakan unsur kompetensi, kemampuan dalam bidangnya dan tidak 
semata-mata berdasarkan ijazah ataupun diploma. Praktek-praktek rekruitmen tenaga kerja melalui sistem koneksi, keluarga, sogok pada akhimya akan merugikan orang lain dan lembaga itu sendiri. Sejak dini perlu ditanamkan pengetahuan tentang dunia kerja, disiplin kerja dan mengurangi ethos "menjadi pegawai negeri lebih terhormat", dari orang-orang yang bekerja wiraswasta. Penanarian disiplin dan integritas dapat dilakukan melalui pemahaman serta penghayatan nilai-nilai moral dan agama.

\section{Pendidikan Islam}

Seperti lembaga pendidikan umüm yang lain, lembaga pendidikan Islam dihadapkan pada tantangan pasaran tenaga kerja yang menurut adanya usaha pembaharuan sistem pendidikan Islam serta sistem pengelolaannya. Pemerintah bersama-sama masyarakat telah berusaha untuk mendorong lembaga-lembaga pendidikan Islam untuk mengembangkan sistem pendidikan dan penyelenggaraan pendidikan sinkron, dan sejalan dengan kebijaksanaan pemerintah melalui Undangundang pendidikan Nasional (UU No. 2 Tahun 1989) serta berbagai Peraturan

Pemerintah yang mengatur pendidikan pada tingkat prasekolah (PP No.27 Tahun 1990), pendidikan Dasar (PP No. 28 Tahun 1990), Pendidikan Menengah (PP No. 29 Tahun 1990) serta pendidikan Tinggi (PP No. 30 Tahun 1990).

Pondok pesantren sebagai lembaga keagamaan di mana dikembangkan dan diajarkan ilmu Agama Islam dalam bentuknya yang lebih tradisional serta madrasah-madrasah dimanadiajarkan ilmu
Agama Islam dengan sistem yang lebih modern (klassikal) berdasar SKB tiga menteri yaitu Menteri Agama, Mendikbud dan Mendagri dihadapkan pada keharusan memasukkan pengajaran ilmu pengatahuan umum dan ' keterampilan dalam kurikulumnya. Hal tersebut diperlukan agar setiap lulusan pesantren dan madrasah memiliki kemampuan untukterjun ke dalam masyarakat dengan pengetahuan serta keterampilan yang dimilikinya sesuai dengan kebutuhan masyarakat. Di sisi lain hal tersebut perlu untuk meningkatkan daya saing pesantren serta madrasah terhadap pendidikan umum mengingat kecenderungan masyarakat semakin meningkat untuk memilih pendidikan umum yang secara langsung dapat menciptakan tenaga kerja yang siap pakai di pasaran kerja lebih-lebih pada saat memasuki masyarakat industri pada Pelita ke'enam mendatang.

Berkaitan dengan arus perubahan sosial memasuki era industrialisasi mendatang maka menurut Prof. Dr: Mukti 'Ali (1984:16) maka sistem pendidikan dan pengajaran Islam yang paling baik di Indonesia adalah sistem pendidikan mengikuti pola pondok pesantren, sedangkan sistem pengajaran mengikuti sistem pendidikan madrasah. Akan tetapi dengan menekankan sistem pendidikan modern dalam mengembangkan pendidikan' Islam telah dirasakan kelemahannya yaitu timbulnya "krisis ulama" yang mendorong Menteri Agama untuk membentuk suatu usaha mencetak ulama melalui MAN Program Khusus yang sampai saat ini telah ada di 5 kota di Indonesia. Permasalahan lain mengenai pondok pesantren, seperti dikemukakan oleh Abdurrahman Wahid (1983:12) adalah integrasi produk pesantren 
ke dalam sistem pendidikan nasional, masalah-wawasan sosial budaya dan sosial ekonomi, kerjasama dengan pihak-pihak lain, hubungan antara keimanan dengan ilmu pengetahuan dan yang tidak kalah penting adalah masalah manajemen dan pembiayaan.

Mengenai pendidikan tinggi, IAIN khususnya tidak lepas dari permasalahan yang sama yaitu menurunnya animo masyarakat untuk masuk ke IAIN, masalah mutuakademis, kesempatan/lapangan kerja bagi para lulusan, relevanși kurikulum dengan kebutuhan masyarakat, serta masalah manajemen dan pembiayaan. Sementara itu Perguruan Tinggi (Islam) Umum di samping dihadapkan pada masalah manajemen, sumber dayamanusia, dan juga dihadapkan pada masalah integrasi antara ilmu pengetahuan umum dengan ilmu pengetahuan Islam dalam berbagai disiplin ilmu yang dikembangkan, pada perguruan tinggi tersebut. Oleh karena itu diperlukan suatu rekonstruksi sistem pendidikan Islam secara terus menerus sejalan dengan tantangan perkembangan masyarakat, ilmu pengetahuan dan teknologi:

Lembaga-lembaga pendidikan Islam sudah seharusnya mempertahankan ciri utama pendidikannya berdasar pada prinsip-prinsippendidikan Islam akan tetapi dituntut pula kemampuannya untuk menjawab tantangan-tantangan perkem- banganmasyarakat, ilmu pengetahuan serta teknologi dengan mengembangkan sistem pendidikan yang dilaksańakan sejalan denganperubahan-perubahan tersebutdemi kelangsungan ekśistensi pendidikan Islam itu sendiri.

\section{DAFTAR BACAAN}

Alan J De Young, economics And American Education, Longman Group Ltd, London, 1989.

Departemen Kebudayaan RI dan USAID, Education and The Economy, The Extemal Efficiency of Education, Jakarta, 1992.

Amien Rais, M. (ED), Islam di Indonesia, Rajawali, jakarta, 1986.

Muljani A. Nurhadi', Pendidikan dan Pembangunan EraIndustrialisasi, IKIP Muhammadiyah Yogyakarta, Nopember 1988.

Prijono Tjiptoherijanto, Masalah Kétenagakerjaan di Indonesia, International Energy Seminar, Semarang, 27 Juli 1988.

Sulistyo,MBA, Strategi Pendidikan Nasional dalam Rangka Tinggal Landas, Seminar ISPI; DIY, 24 Februari 1988.

Sumamo, Kaitan Kebutuhan Masyarakat akan Pendidikan Tinggi dengan Pembangunan Nasional, FIP IKIP Yogyakarta, 19 Juli 1986.

.Yudo Swasono, Perencanaan Tenaga Kerja di Indonesia, Majalah Prisma 4 April 1982. 